\title{
Social Security for Women Workers in Unorganized Sector: A Study
}

\author{
Ranjith Kumar, Ramya M \\ Research Scholar, Department of Studies in Economics, Kuvempu University, \\ Jnana Sahyadri, Shankaraghatta, Shivamogga, Karnataka, India
}

\begin{abstract}
Social security means the overall security for a person in the family, work place and society. Social security is a system to meet the basic needs as well as contingencies of life in order to maintain an adequate standard of living. It is not a charity rather a right. But women workers are living below the minimum accepted standards without adequate facilities and having very lower income that did not meet their daily needs of life. Objective of the study to know the present status of women workers in unorganized sector and to know the social. Security Act in India, the study is based on purely from secondary sources collected form different articles newspaper and websites.
\end{abstract}

\section{KEYWORDS: Social Security, Unorganized}

\section{INTRODUCTION}

Social security is that government, which is the symbol and representative of society is responsible for fixing a minimum standard of living for all its citizens. Social Security is an instrument for social transformation and progress. The tem "Unorganized" is often used in the Indian context to refer to the vast numbers of women and men engaged in different forms of employment. According to ILO "Social Security is the protection which society provides for its members through a series of Public measure, against the economic and social distress that otherwise would be caused by the stoppage or substantial prediction of earning resulting from sickness, maternity, employment, injury, unemployment, invalidity, old age and death."

Social Security of women have been widely and repeatedly discussed by the media and the government of India from time to time. However all the government acts are gender sensitive, although never dimensions have been added to make ensure women rights in the modern. Society the Hindu Marriage Act of 1956 explains the divisions of property in a Hindu joint family and explains the right of women. The maternity leaves for working class women. In case of separation, the women are give equal rights and the highest degree of emotional. Security hence there are many laws have been enacted by the government agencies to provide in built support to the society especially the women.

\section{Review of Literature}

The ILO definition (1972) incorporated the idea that informal sector had untapped development potential because of its flexibility and potential for creative response to economic change. The only specificity being absence of workers rights and social security in every other way, both form part of an integral whole.

According to G. Rajendran and S. Hema (2015) concluded that they are the most vulnerable and deprived section of the society in the need of protection, security, benefits and assistance.

Anthony P. D'Souza (2013) focused the status and contribution of unorganized sector focused more on the challenges and problems faced by the youth in selecting job as self-employment.

\section{Objective of the Study}

1. To study the present status of women workers in unorganized sector

2. To study the social security Act in India

\section{Methodology}

Data sources the study is based on purely secondary data collected form newspaper and websites etc.

\section{Analysis and Interpretation}

The Indian council of social science research, New Delhi has made several studies in a wide range of occupations in the unorganized sector on women. Studies which were conducted in the various part of the country reveals the awful conditions of the women labourers in the unorganized sector. It has been observed that a significant percentage of the jobs in this sector are managed by women drawn from lower caste and lower class women. Ignorance, tradition bound attitudes, illiteracy, lack of skills, seasonable nature of employment, heavy physical work of different types, long hours of work with limited payment, discrimination in wage structures of men and women, lack of guarantee of minimum wage, lack of job security, lack of comprehensive legislation to cover these labourers in unorganized informal sector., lack of minimum facilities at the work-site, ill-treatment, migration and disintegration of families, bondage and alienation, etc. are the characteristics of the employment women in the sector.

Most of the women are found to be employed in agricultural activities and in the unorganized sector. The employment of women is high in the unorganized sector such as part time helpers in households, construction center, match and beedi industries etc. An estimate by the world bank show that $90 \%$ of the women working in the unorganized sector are not included in the official statistics and then work is undocumented and considered as disguised wage work, unskilled, low paying and do not provide benefits to the workers. Statistics show that vast majority of Indian work in 
agriculture where $55 \%$ of the population is female agricultural workers and $30 \%$ of the men are labourers and not cultivators.

Labouring women in the unorganized sector are an important segment on the labour force in India. According to an estimate of National Commission of Self Employment of women, $94 \%$ of the total female work force operates in the organized sector. They do arduous work as wage earners, piece rate workers, casual labour and paid family labour. The coverage of labour laws has not benefited there women workers in many areas of wages, working conditions, maternity benefits and social security.

Characteristics of Women Workers

\begin{tabular}{|l|c|c|c|}
\hline \multicolumn{1}{|c|}{ Particulars } & Male & Female & Rural Female \\
\hline Total workers (in million) & 309.4 & 148.0 & 124.0 \\
\hline Labour Force participation Rate & 56.0 & 29.0 & 33.3 \\
\hline Work Force participation Rate & 54.7 & 28.3 & 32.7 \\
\hline Percentage of Casual Labour in total work force & 27.5 & 30.0 & 32.6 \\
\hline \% of unorganized sector workers in total workforce & 84.0 & 91.3 & 94.5 \\
\hline \% of workers in Agriculture and Allied activities & 48.9 & 72.8 & 83.34 \\
\hline \% of out of school children in Relevant Age (5-14 years) & 15.5 & 20.7 & 23.5 \\
\hline Mean Years of Schooling (unorganized Non-Agricultural workers) & 6.1 & 3.7 & 2.9 \\
\hline Wage Rate of rural agricultural labourers (Per Mandy) & 47.9 & N A & 33.1 \\
\hline Wage rate of Rural Non-agricultural Labourers (Per Mandy) & 67.5 & N A & 44.0 \\
\hline \% of casual labourer (Rural) not getting National minimum wage of 66 & 78.0 & N A & 95.6 \\
\hline
\end{tabular}

Source: National Commission for Enterprises in the Unorganized Sector (NCEUS)

This table highlights some glaring problems planning the unorganized sector. Even at a cursory glance it is obvious that the balance is titled heavily against women workers of the unorganized sector.

\section{Social Security in India}

Many nations in the Asia and Pacific have been finding out alternate solutions for the social security protection of various groups. Each nation has come up with some difficulty or the other.

Lets us bring our focus to one such nation, the Republic of India. India is a developing nation with one sixth of the world human population. The Social Security Plans implemented in India have been post-independence and has been limited to organize and some sections of the unorganized sector. The growing population has been working the government of India for far too long. Policy makers of the government have been trying to implement schemes with the increasing demands coming from the people hampering all efforts policy makers do. The devoid created by the disorganization of once a joint family system has made more and more families secured, vulnerable and out of the social security schemes.

Social Security in India have been addressed by the Central Government through various Acts:

1. Workmen's Compensation Act, 1923

2. Maternity Benefits Act, 1961

3. Employment State Insurance Scheme, 1948

4. Employment Provident Fund Scheme, 1925

5. Coal Mines Provident Fund Bonus Scheme, 1948

6. Employees Provident Fund Act, 1952

7. Employees Family Pension Scheme, 1971

8. The Assam Tea Plantation Provident Fund Act, 1965

9. The Seamen's Provident Fund Act, 1966

10. Safety health and welfare of Dock Workers (The Dock Workers Regulation of Employment Act, 1948)

11. The Survivor-Ship Pension Scheme, 1971

12. The Way-off and Retirement Compensation (Industrial Dispute Act, 1947 with amendment in 1953)
13. The Old Age Pension Scheme (The Family Pension Scheme, 1964)

14. Gratuity Trust Funds

15. Unemployment Insurance

16. Integrated Social Security Scheme

The Schemes mentioned above, have been discussed and amended by the government of India from time to time. Many more schemes are being discussed today. The government is trying to cover aspects such as environment, habitat, health and nutrition in a larger space of Social Security.

\section{Suggestions}

$>$ A comprehensive law is needed to protect the right of women workers in unorganized sector.

$>$ Adequate training should be provided to women workers

$>$ There is need of more effective Social Security programme

$>$ Mass media can play a great role to change social outlook towards women workers in informal sector

> Basic Training Programme Provide to women workers in unorganized sector

\section{Conclusion}

In India unorganized women workers face serious problems and constraints related to work such as lack of continuity, insecurity, wage discrimination, unhealthy job relationship, absence of medical and accident case etc. The exploitation of women workers in unorganized sector happens both horizontally and vertically. It is time to address the issues and discuss the kind of policy reforms and institutional changes required for the emancipation and empowerment of unorganized women worker force with support of Social Security Scheme. 
There are various reasons for pitiable conditions of women in unorganized sector. The Central and State government had launched many schemes for providing support to women but there are not sufficient to overcome the problem of women workers in unorganized sector. There is need to effective implementation of these schemes.

\section{References}

[1] Bhatt E. (1988). "National Commission on Self Employed Women's the Women in the Informal Sector", The Report by NCEUS.
[2] Kumar S. (1989). "Women Workers in Unorganized Sector in India", Yojana, Vol. 33, No. 22.

[3] Singh Mohinder (1989). "Women and Development Process in India", Khadi Gramodyog, Vol. XXXV, No. 4.

[4] Varshney S. (2011). "Role of Women in Informal Sector", Economic Affairs, Vol. 56, No. 2.

[5] www.socialsecurity.gov/women

[6] http://www.tarj.in

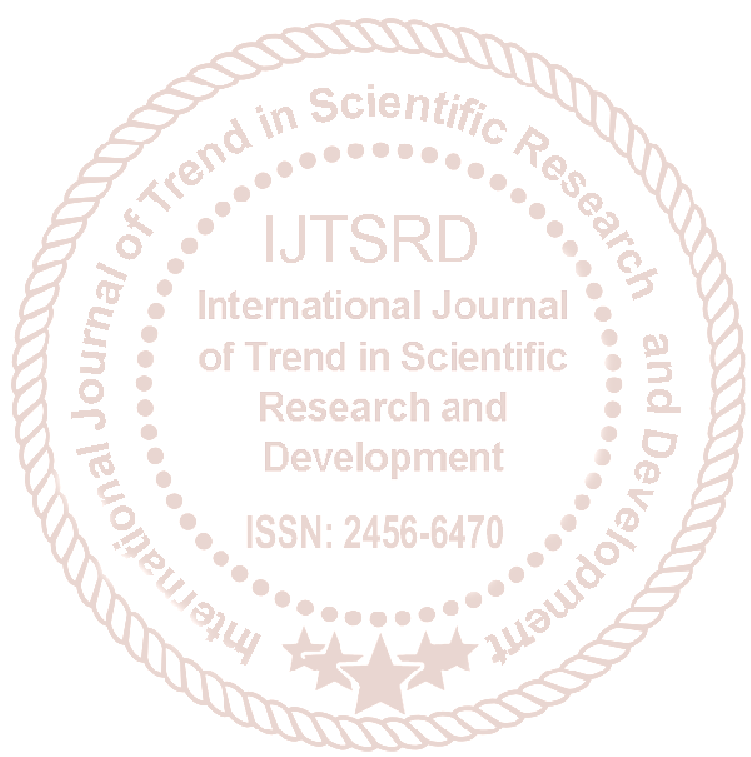

